\title{
Development and application of an enzyme linked immunosorbent assay for Clostridium perfringens type A enterotoxin
}

\author{
BARBARA A BARTHOLOMEW, MF STRINGER, GN WATSON, RJ GILBERT \\ From the Food Hygiene Laboratory, Central Public Health Laboratory, London NW9
}

SUMMARY An enzyme linked immunosorbent assay (ELISA) has been developed to quantitate iv faecal Clostridium perfringens enterotoxin in the investigation of $C$ perfringens food poisoning. N The sandwich ELISA could be carried out in $24 \mathrm{~h}$ and was sensitive enough to detect as little as 음 $5 \mathrm{ng} / \mathrm{g}$ of enterotoxin in faeces. Specificity of the assay was shown by comparing results with those obtained from other standard toxin assays, such as double gel diffusion and counterimmunoelectrophoresis, and by the assay of faecal material from control groups. By means of the ELISA method, 515 faecal samples from 50 separate outbreaks of $C$ perfringens food poisoning were examined, together with 21 food samples from 12 of the outbreaks. A clear distinction was noted between faecal samples collected on the first two days of an outbreak, where $77 \%$ were enterotoxin positive, and those specimens collected later than the second day, when only $33 \%$ had detectable enterotoxin. The ELISA is recommended as a valuable tool in the investigation of $C$ perfringens foodborne illness.

$C$ perfringens is widely distributed in a variety of foods, especially meat and poultry products, and is recognised as an important cause of food poisoning throughout the world.' During the period 1970-82, there were 128714 reported cases of food poisoning in England and Wales: Salmonella accounted for $103052(80 \%)$ cases and $C$ perfringens was responsible for $21342(17 \%)$ cases. ${ }^{23}$ It has been firmly established that an enterotoxin produced in the intestine following sporulation of ingested vegetative cells is responsible for the illness. ${ }^{4}$ Confirmation of $C$ perfringens food poisoning depends on the isolation of large numbers $\left(>10^{\circ} / \mathrm{g}\right)$ of the organism from faecal specimens and the subsequent demonstration of a common serological type in these and in the incriminated food. The ability of these isolates to produce enterotoxin in vitro may be of importance, but the problems associated with obtaining good sporulation and subsequent enterotoxin production in vitro are well known and make this approach unsuitable. ${ }^{5}$ An alternative approach is to show the presence of enterotoxin in faeces, and this may be particularly valuable when serological confirmation is not possible. This study

Accepted for publication 22 October 1984 describes the development of a rapid and sensitive $\mathbb{D}$ immunoassay capable of detecting low concentra- $\overrightarrow{\vec{B}}$ tions of enterotoxin in crude faecal extracts. The $\frac{3}{3}$ sandwich ELISA has been applied to the study of $50 \supset$ outbreaks of $C$ perfringens food poisoning in the United Kingdom during the period April 1983 to August 1984.

\section{Material and methods}

\section{BACTERIAL STRAIN}

Cperfringens type A strain NCTC 8239 was음 obtained in cooked meat medium from R Skjelk- $\rightarrow$ våle, Norwegian Food Research Institute, Oslo.

\section{PURIFICATION OF ENTEROTOXIN}

Enterotoxin, $90-100 \%$ pure as determined by polyacrylamide gel electrophoresis, was prepared $\omega$ from $C$ perfringens type A NCTC 8239 by a modification $^{6}$ of the method of Granum and Whitaker'e and freeze dried in $500 \mu \mathrm{g}$ amounts.

PREPARATION OF ANTISERUM AND CONJUGATE Rabbit antiserum against purified $C$ perfringens $\frac{}{\Phi}$ enterotoxin was prepared by the method of $\stackrel{\cap}{\mathscr{P}}$ Genigeorgis et $^{a^{8}}{ }^{8}$ as described by Bartholomew and ${ }^{\circledR}$ Stringer. ${ }^{6}$ The immunoglobulin $\mathrm{G}(\mathrm{IgG})$ fraction of 
the antiserum was isolated by the technique of Steinbuch and Audran" and freeze dried. Horseradish peroxidase (type VI; Sigma Chemical Co Ltd, Poole, Dorset) was conjugated to the rabbit antitoxin IgG by the method of Nakane and Kawaoi. ${ }^{10}$ Unlabelled material was separated by gel filtration on a Sephacryl S200 column $(0.9 \times 60 \mathrm{~cm})$. Aliquots of the conjugate were stored at $-20^{\circ} \mathrm{C}$ in the presence of bovine serum albumin $(10 \mathrm{mg} / \mathrm{ml})$.

\section{SOURCE OF SPECIMENS}

Food samples and faecal specimens implicated in $C$ perfringens outbreaks from April 1983 to August 1984 were obtained from public health and hospital laboratories. Faecal specimens for control studies came from the following three sources: (a) asymptomatic volunteers, who were laboratory workers aged $25-60 ;(b)$ patients with diarrhoea referred to the MRC Clinical Research Centre, Harrow, for $C$ difficile screening and positive for $C$ difficile; and (c) patients as described in (b) but negative for $C$ difficile and other commonly investigated pathogens and thus designated as suffering from diarrhoea of unknown cause.

PREPARATION OF FOOD AND FAECAL EXTRACTS Food samples and faecal specimens $(2 \mathrm{~g})$ were vortexed in $2 \mathrm{ml}$ of $0.01 \mathrm{M}$ phosphate buffer $\mathrm{pH} 7.2$ containing $0 \cdot 15 \mathrm{M} \mathrm{NaCl}$ (PBS). The specimen was then centrifuged $\left(15000 \mathrm{rpm}\right.$ for $30 \mathrm{~min}$ at $\left.4^{\circ} \mathrm{C}\right)$ and the supernatant fluid passed through a $0.22 \mu \mathrm{m}$ Millex-GS filter (Millipore UK Ltd, Harrow, Middlesex).

\section{SEROLOGICAL AND BACTERIOCIN TYPING}

The serological types of isolates of $C$ perfringens associated with the 50 food poisoning outbreaks were determined." In some instances bacteriocin typing ${ }^{12}$ was also carried out.

\section{ENTEROTOXIN ASSAYS}

Double gel diffusion and counterimmunoelectrophoresis were carried out as described elsewhere. ${ }^{11} 13$

\section{ELISA PROCEDURE}

The sandwich ELISA technique described by Notermans ${ }^{14}$ was used with some modification. Each well of an Immulon microtitre plate (Dynatech Laboratories Ltd, Billingshurst, Sussex) was coated with rabbit antienterotoxin IgG $(0.1 \mathrm{ml}$ of $5 \mu \mathrm{g} / \mathrm{ml}$ solution in PBS). The plate was sealed and incubated overnight at $22^{\circ} \mathrm{C}$. The plate was then washed four times with PBS containing $0.05 \%$ Tween 20 (PBS-Tween) using an Ilacon plate washer (Ilacon Ltd, Tonbridge, Kent).
Enterotoxin standards $(0-50 \mathrm{ng} / \mathrm{ml})$ and test samples $(0 \cdot 1 \mathrm{ml}$, diluted with PBS-Tween) were added to the antibody coated plate, which was sealed and incubated at $37^{\circ} \mathrm{C}$ for $90 \mathrm{~min}$. The plate was washed as before and incubated for a further $90 \mathrm{~min}$ at $37^{\circ} \mathrm{C}$ in the presence of antienterotoxin IgG-horseradish peroxidase conjugate $(0.1 \mathrm{ml}$, diluted with PBSTween containing $1 \%$ normal rabbit serum). After the washing procedure $0.1 \mathrm{ml}$ of $\mathrm{ABTS}-\mathrm{H}_{2} \mathrm{O}_{2}$ solution-that is, $0.4 \mathrm{mM} \quad 2,2^{\prime}$-azino-di(3ethylbenzthiazoline-6-sulphonate) (ABTS) and $1.3 \mathrm{mM} \mathrm{H} \mathrm{H}_{2} \mathrm{O}_{2}$ in $0.1 \mathrm{M}$ citrate phosphate buffer, pH4.0 - was added to each well and the plate incubated for $30 \mathrm{~min}$ at room temperature. The absorbance was read at $405 \mathrm{~nm}$ with a MR580 microplate reader (Dynatech Laboratories).

A set of eight enterotoxin standards, generated by double dilution of a $50 \mathrm{ng} / \mathrm{ml}$ stock enterotoxin solution, was included in each plate and a standard curve was plotted with optical density on the $y$ axis and log enterotoxin concentration on the $x$ axis (Figure). To assess, initially, whether a sample was enterotoxin positive it was included in duplicate with an equal volume of a $1 / 5(\mathrm{vol} / \mathrm{vol})$ dilution in PBS-Tween of either normal rabbit serum $(\mathrm{N})$ or antienterotoxin antiserum (P). If a ratio of $\mathrm{N}: \mathrm{P}>2 \cdot 1$ was obtained the sample was considered positive. Eight doubling dilutions of the sample solutions were also made to ensure that some values would be within the range of the standard curve and the average of these was taken as the final result. A computer program, written in FORTRAN IV, was used to facilitate calculation of results.

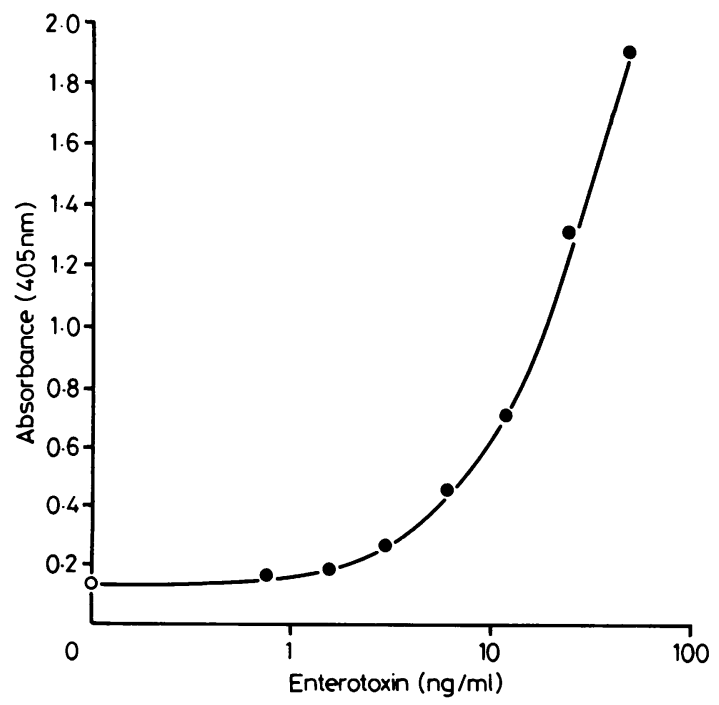

Standard curve for ELISA determination of Clostridium perfringens enterotoxin 
To determine the optimum coating and conjugate concentrations the assay was performed with a range of each. The concentrations chosen were those which gave maximum sensitivity together with maximum specificity-that is, the highest optical density with the highest N:P ratio.

\section{STUDIES USING THE ELISA TECHNIQUE}

Faecal'samples (515) from 50 separate outbreaks of $C$ perfringens food poisoning were examined, together with 21 food samples from 12 outbreaks. In addition, 79 faecal specimens from three different control groups were tested. Recovery of toxin was determined by the addition of $50 \mathrm{ng} / \mathrm{ml}$ of enterotoxin to a random selection of positive and negative faecal extracts. In order to compare the ELISA technique with other standard immunological tests a group of 44 specimens was assayed for toxin by ELISA, counterimmunoelectrophoresis, and double gel diffusion.

\section{Results}

A standard curve was produced using reference enterotoxin for each microtitre plate used (Figure). The limit of detection, a value $2 \cdot 1$ times the blank value, was normally about $2.5 \mathrm{ng} / \mathrm{ml}$ extract-that is, $5 \mathrm{ng} / \mathrm{g}$ of faeces. When a known amount of enterotoxin $(50 \mathrm{ng} / \mathrm{ml})$ was added to 16 faecal extracts the percentage recoveries ranged from $72 \%$ to $124 \%$, with a mean of $101 \%$. Results of studies of 50 outbreaks of $C$ perfringens food poisoning are presented in Tables 1 and 2. Although specimens should be taken within the first two days of the development of symptoms, there is often an unavoidable delay. Since excretion of enterotoxin declines after this initial period, the data have been divided into two tables depending on when the samples were collected. Thus 228 of 294 samples (77\%) taken within two days of illness were enterotoxin positive (Table 1) compared with 74 of $221(33 \%)$ of those collected later (Table 2). Of 21 food samples examined from 12 of the outbreaks, three were positive with concentrations of 8,26 , and $52 \mathrm{ng} / \mathrm{g}$ (Table 3). Faecal specimens from the three control groups were all enterotoxin negative (Table 4).

Results obtained when the ELISA was compared with two other immunoassays for enterotoxin are presented in Table 5. Double gel diffusion was not used quantitatively and had a limit of detection of $2 \mu \mathrm{g} / \mathrm{g}$, whereas toxin values above $1 \mu \mathrm{g} / \mathrm{g}$ were quantitated by counterimmunoelectrophoresis.

Table 1 Detection of enterotoxin by ELISA in faecal specimens collected on days 1-2 of 28 Clostridium perfringens outbreaks

\begin{tabular}{|c|c|c|c|c|c|c|c|}
\hline \multirow[t]{2}{*}{ Laboratory of investigation } & \multirow{2}{*}{$\begin{array}{l}\text { No of } \\
\text { specimens } \\
\text { tested }\end{array}$} & \multicolumn{4}{|c|}{ Enterotoxin $(\mu g / g)$} & \multirow{2}{*}{$\begin{array}{l}\text { No of enterotoxin } \\
\text { positive specimens } \\
(\%)\end{array}$} & \multirow{2}{*}{$\begin{array}{l}\text { Outbreak } \\
\text { confurmation } \\
\text { by serotyping }\end{array}$} \\
\hline & & $N D$ & $<1$ & $1-100$ & $>100$ & & \\
\hline PHL Stoke & 12 & 1 & 2 & 7 & 2 & $11(92)$ & + \\
\hline PHL Hereford & 6 & 2 & 1 & 3 & 0 & $4(67)$ & + \\
\hline PHL Stoke & 26 & 2 & 2 & 17 & 5 & $24(92)$ & + \\
\hline Torbay Hospital & 12 & 3 & 0 & 8 & 1 & $9(75)$ & + \\
\hline PHL Wolverhampton & 7 & 1 & 4 & 2 & 0 & $6(86)$ & + \\
\hline PHL Epsom & 5 & 1 & 1 & 2 & 1 & $4(80)$ & + \\
\hline Dunston Hill Hospital, Gateshead & 22 & 1 & 2 & 12 & 5 & $21(95)$ & + \\
\hline Basildon Hospital & 17 & 2 & 4 & 10 & 1 & $15(88)$ & No cultures received \\
\hline PHL Manchester & 3 & 1 & 1 & 1 & 0 & $2(67)$ & + \\
\hline PHL Central Middlesex Hospital & 4 & 0 & 2 & 2 & 0 & $4(100)$ & + \\
\hline PHL Manchester & 4 & 0 & 0 & 3 & 1 & $4(100)$ & + \\
\hline PHL Birmingham & 11 & 1 & 1 & 8 & 1 & $10(91)$ & + \\
\hline PHL Nottingham & 5 & 2 & 0 & 3 & 0 & $3(60)$ & + \\
\hline PHL Sheffield & 6 & 1 & 1 & 3 & 1 & $5(83)$ & + \\
\hline PHL Southampton & 9 & 3 & 6 & 0 & 0 & $6(67)$ & + \\
\hline City Hospital, Aberdeen & 16 & 2 & 0 & 7 & 7 & $14(88)$ & + \\
\hline Ashford Hospital & 8 & 2 & 5 & 1 & 0 & $6(75)$ & $-*$ \\
\hline PHL Leeds & 10 & 2 & 7 & 1 & $\mathbf{0}$ & $8(80)$ & + \\
\hline City Hospital, Aberdeen & 9 & 1 & 6 & 2 & 0 & $8(89)$ & - \\
\hline PHL Epsom & 6 & 1 & 2 & 2 & 1 & $5(83)$ & - \\
\hline PHL Preston & 15 & 5 & 9 & 1 & $\mathbf{0}$ & $10(67)$ & + \\
\hline PHL Leicester & 21 & 13 & 8 & $\mathbf{0}$ & 0 & $8(38)$ & \\
\hline PHL Oxford & 6 & 3 & 2 & 1 & 0 & $3(50)$ & No cultures received \\
\hline Llandough Hospital, S Glam & 15 & 5 & 6 & 3 & 1 & $10(67)$ & + \\
\hline $\begin{array}{l}\text { PHL Brighton } \\
\text { Crawley Hospital, Sussex }\end{array}$ & 22 & 8 & 6 & 6 & 2 & $14(64)$ & + \\
\hline PHL Bath & 5 & 0 & 4 & 1 & 0 & $5(100)$ & + \\
\hline Llandough Hospital, S Glam & 8 & 2 & 1 & 5 & $\mathbf{0}$ & $6(75)$ & - \\
\hline PHL Lincoln & 4 & 1 & 3 & 0 & 0 & $3(75)$ & + \\
\hline Total & 294 & 66 & 86 & 110 & 29 & $228(77)$ & \\
\hline
\end{tabular}

*Outbreak confirmed by bacteriocin typing. ND = not detected. 
Table 2 Detection of enterotoxin by ELISA in faecal specimens collected later than day 2 of 22 Clostridium perfringens outbreaks

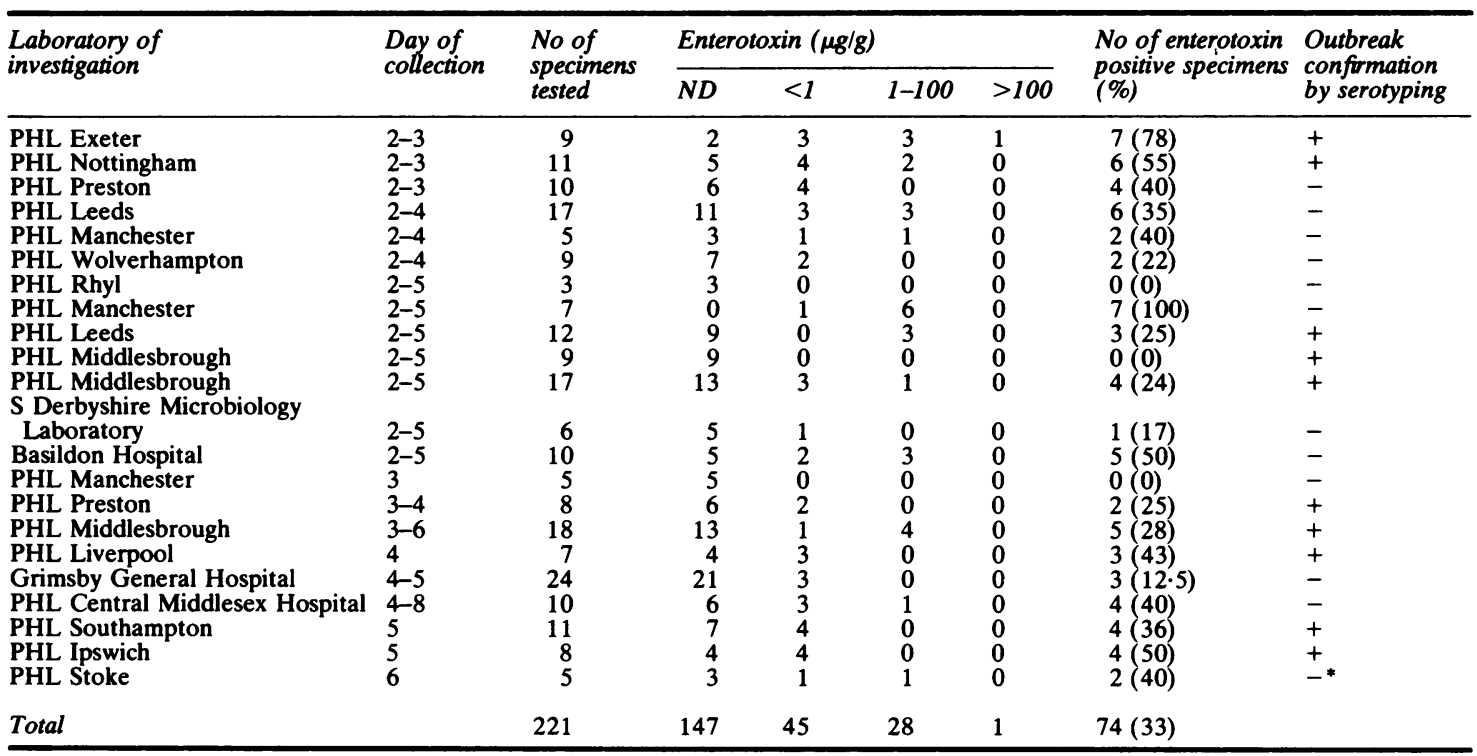

* Outbreak confirmed by bacteriocin typing. ND = not detected.

Table 3 Detection of enterotoxin by ELISA in food samples implicated in Clostridium perfringens outbreaks

\begin{tabular}{|c|c|c|c|c|c|}
\hline Outbreak & Food examined & $\begin{array}{l}\text { Enterotoxin } \\
(\mu g / g)\end{array}$ & $\begin{array}{l}\text { Incubation time } \\
\text { for symptoms (h) }\end{array}$ & $\begin{array}{l}\text { No of } C \text { perfringens } \\
\text { isolated from food } \\
\text { (cfulg) }\end{array}$ & $\begin{array}{l}\text { Isolation of a serotype } \\
\text { from food in common } \\
\text { with faeces }\end{array}$ \\
\hline $\begin{array}{l}1 \\
2 \\
3\end{array}$ & $\begin{array}{l}\text { Stew } \\
5 \text { suspect foods } \\
5 \text { suspect foods including } \\
\text { chicken curry }\end{array}$ & $\begin{array}{l}0 \cdot 008 \\
\text { ND } \\
\text { ND } \\
0 \cdot 026\end{array}$ & $\begin{array}{l}12 \\
12 \\
12\end{array}$ & $\begin{array}{l}10^{6} \\
\text { ND } \\
\text { ND } \\
\text { ND }\end{array}$ & $\begin{array}{l}\text { NK } \\
- \\
- \\
-\end{array}$ \\
\hline 4 & Beef, carrots, potatoes & ND & $6-8$ & $+^{*}$ & + \\
\hline 5 & Roast beef & ND & $6-8$ & $10^{4}$ & + \\
\hline 6 & Steak and kidney pie & ND & 9 & $+^{*}$ & + \\
\hline 7 & Chicken, peas, potatoes & ND & NK & $+^{*}$ & + \\
\hline 8 & Minced beef & 0.052 & NK & $10^{6}$ & + \\
\hline 9 & Ham & ND & 12 & $10^{4}$ & + \\
\hline & Beef & ND & & $10^{7}$ & + \\
\hline 10 & Minced beef & ND & $12-18$ & ND & - \\
\hline 11 & Roast beef and coleslaw & ND & NK & $+^{*}$ & + \\
\hline 12 & Roast beef & ND & 12 & $+^{*}$ & - \\
\hline
\end{tabular}

$\mathrm{ND}=$ none detected; $\mathrm{NK}=$ not known; ${ }^{*} C$ perfringens isolated but numbers not known.

Table 4 Detection of enterotoxin by ELISA in faecal specimens from control groups

\begin{tabular}{llll}
\hline Control groups* & No in group & No of samples & No enterotoxin positive \\
\cline { 3 - 4 } & & No tested & 0 \\
\hline Asymptomatic volunteers & 15 & 43 & 0 \\
$\begin{array}{l}\text { Patients with C difficile diarrhoea } \\
\text { Patients with chronic diarrhoea of }\end{array}$ & 12 & 12 & 0 \\
unknown aetiology & 22 & 24 & 0 \\
Total & 49 & 79 & \\
\hline
\end{tabular}

* See text for details. 
Table 5 Comparison of methods for detecting enterotoxin in faecal specimens

\begin{tabular}{llll}
\hline Method & No tested & \multicolumn{2}{l}{$\begin{array}{l}\text { Enterotoxin } \\
\text { positive samples }\end{array}$} \\
\cline { 3 - 4 } & & No & $\%$ \\
\hline Double gel diffusion & 44 & 30 & 68 \\
Counterimmunoelectrophoresis & $41^{*}$ & 27 & 66 \\
ELISA & 44 & 39 & 89 \\
\hline
\end{tabular}

*Three samples not tested by counterimmunoelectrophoresis.

Thus it was a reflection of the greater sensitivity of the ELISA that this technique detected toxin in $89 \%$ of samples compared with $68 \%$ and $66 \%$ by double gel diffusion and counterimmunoelectrophoresis respectively.

\section{Discussion}

During the course of this work a number of papers have been published describing ELISA.procedures for $C$ perfringens enterotoxin. ${ }^{15-18}$ The technique described in this paper is equally as rapid, sensitive, and specific as these other methods, but, in addition, its value as an epidemiological tool has been established in the study of 50 outbreaks of $C$ perfringens food poisoning.

If microtitre plates are precoated the previous night or stored at $-70^{\circ} \mathrm{C}$, our assay, like that described by McClane and Strouse,,$^{15}$ can be easily completed within a working day. But since our method and that of Notermans et al ${ }^{18}$ have one fewer step than the four layer sandwich of McClane and Strouse they are even more rapid. In order to achieve their high degree of sensitivity Olsvik et al $^{16}$ designed a four layer sandwich technique with an assay time of $68 \mathrm{~h}$. As suggested by McClane and Strouse, a desire for increased rapidity will inevitably result in reduced sensitivity. Our technique is capable of detecting $5 \mathrm{ng} / \mathrm{g}$ of faeces, which is of the same order of sensitivity as that achieved by Olsvik et al for faeces. In contrast, McClane and Strouse justified the use of their technique of lower sensitivity $(0.5 \mu \mathrm{g} / \mathrm{g})$ on the basis that previously reported toxin concentrations in outbreak specimens range from 0.5 to $16 \mu \mathrm{g} / \mathrm{g}$. In our studies on 302 positive specimens, however, $116(38 \%)$ contained less than $0.5 \mu \mathrm{g} / \mathrm{g}$ and therefore an assay with a minimum sensitivity of $0.5 \mu \mathrm{g} / \mathrm{g}$ would not detect toxin in more than one third of the positive faeces associated with outbreaks. A much wider range $(12 \mathrm{ng} / \mathrm{g}$ $140 \mu \mathrm{g} / \mathrm{g}$ ) of toxin concentrations was found in the 302 positive specimens than previously reported in other studies, ${ }^{1619}$ where a smaller number of faeces (fewer than 10) were examined.

Unlike the other methods described, ${ }^{15-17}$ ours and that of Notermans et $a^{18}$ are double antibody sand- wich techniques which require the preparation of specific antienterotoxin enzyme conjugate, whereas the others need antibodies raised in two different species. In our experience preparation of conjugate has not presented any difficulties but there are obvious advantages in the use of commercially available anti-IgG-enzyme conjugate when several antigens are under simultaneous investigation.

Allowing for differences in sensitivity, good correlation was achieved between the ELISA and double gel diffusion and counterimmunoelectrophoresis. Specimens from all three control groups including cases of diarrhoea not due to $C$ perfringens were negative for toxin. This provided additional confirmation that the ELISA was specifically detecting $C$ perfringens enterotoxin and not other faecal components. Some workers have had problems in applying the ELISA technique to the study of crude faecal extracts - for example, Notermans et al $^{18}$ have described interference by faecal material even when faeces were diluted $1 / 10^{5}$. Initially, we encountered some difficulty due to non-specific effects but this was overcome by the addition of $1 \%$ normal rabbit serum with the conjugate solution. The rabbit serum acts by diluting out any enzyme labelled antibodies to non-enterotoxin faecal proteins.

Another area of difficulty concerns extraction and recovery of toxin from faecal material. The recovery results obtained in this study are encouraging and show the ability of the ELISA to quantitate accurately enterotoxin present in faecal extracts. In contrast, when Narayan et al ${ }^{17}$ attempted to assess recovery of enterotoxin added to normal rabbit faeces before extraction only $39 \%$ was recovered, and this may reflect a problem in extraction rather than an inability to estimate toxin in faeces. The fact that most of the samples we studied were diarrhoeal enabled us to make extracts with the minimum of dilution, whereas most other studies have had to make $1 / 10$ dilutions owing to the solid nature of the normal stools. Thus we were able to avoid unnecessary dilution of faecal enterotoxin.

The diarrhoeal nature of specimens collected within the first two days of illness emphasised the clear relation between day of collection and ability to detect toxin. There was an obvious distinction between samples collected on the first two days and those collected later (Tables 1 and 2). Not only were more outbreaks serologically confirmed $(85 \%$ compared with $43 \%$ ) but more samples had detectable toxin (77\% compared with $33 \%$ ) when less than two days had elapsed since the onset of symptoms. In addition, most positive samples in the first group had toxin concentrations between 1 and $100 \mu \mathrm{g} / \mathrm{g}$, whereas most samples in the latter group had faecal toxin of less than $1 \mu \mathrm{g} / \mathrm{g}$. 
Experimental food poisoning in monkeys has shown that maximum excretion of faecal enterotoxin occurs in the diarrhoeal stage of illness, diminishes gradually, and is absent two days after ingestion of viable cells of $C$ perfringens. ${ }^{20}$ These findings were substantiated by carrying out a monkey feeding experiment in which monkeys were fed $10^{4}$ viable cells and $10^{3}$ spores (unpublished work carried out in collaboration with the PHLS Centre for Applied Microbiology and Research, Porton Down). The highest level of enterotoxin $(70 \mu \mathrm{g} / \mathrm{g})$ was detected after $20 \mathrm{~h}$; at $44 \mathrm{~h}$ only $0 \cdot 1 \mu \mathrm{g} / \mathrm{g}$ was present, and after $48 \mathrm{~h}$ toxin was not detected.

From these findings it is evident that in the investigation of suspected $C$ perfringens food poisoning, faecal specimens must be collected as soon as possible in the acute stage of diarrhoea. The presence of detectable toxin in outbreak faeces may also be influenced by the way in which specimens are handled and stored before laboratory examination, since it is not unreasonable to postulate that bacterial degradation of enterotoxin can occur. Notermans et al, ${ }^{18}$ however, have implied that faecal enterotoxin is stable for at least 20 days at room temperature, but since they give no quantitative results this is an obvious area for further investigation.

$C$ perfringens enterotoxin is produced in vivo after sporulation, and symptoms of food poisoning usually occur between 8 and $20 \mathrm{~h}$ after consumption of incriminated food. It has been suggested that symptoms occurring within $6 \mathrm{~h}$ may be due to preformed enterotoxin in food. ${ }^{21}$ During a study of the ability of $C$ perfringens to produce enterotoxin in foods, Naik and Duncan examined a food sample associated with an outbreak. Enterotoxin was detected in this food, and in addition the strain of $C$ perfringens isolated was also enterotoxigenic. In our investigation we were able to examine 21 foods implicated in 12 outbreaks and toxin (8-52 $\mathrm{ng} / \mathrm{g}$ ) was detected in three. Incubation time for the 12 outbreaks ranged from 6 to $18 \mathrm{~h}$ and there was no correlation between incubation time and the presence of toxin in food. It is not possible to know whether these concentrations of toxin were present in the foods at the time of ingestion or were produced during subsequent handling and storage after the incident. Skjelkvåle and Uemura $^{22}$ have shown that at least $8 \mathrm{mg}$ of pure toxin was required to provoke diarrhoea when administered orally to human volunteers whose gastric juice had been neutralised with sodium bicarbonate. It therefore seems unlikely that the relatively small amounts of toxin detected in the three foods in this study could induce early onset illness. In laboratory experiments several workers have looked at sporulation and enterotoxin production in various beef and poultry products ${ }^{2123}$ and detected enterotoxin at concentrations of up to $24 \mu \mathrm{g} / \mathrm{g}$. It would therefore seem possible for appreciable amounts of enterotoxin to be produced in foods and these could cause illness providing the toxin retains its activity during passage through the stomach.

In conclusion, the double antibody ELISA technique described here has proved to be a useful epidemiological tool when applied to the study of 50 outbreaks of food poisoning due to $C$ perfringens. Detection of faecal enterotoxin using this method may supplement information obtained by serological typing of the isolates or replace it when serological confirmation is not possible for one or more of the following reasons: the $C$ perfringens isolates are non-typable with the range of antisera available; they may be too rough to type; the faecal specimens may have been collected some time after the onset of symptoms, resulting in a mixture of serotypes due to re-establishment of the normal intestinal flora. In this study 14 of 16 outbreaks which were not serologically confirmed had some samples containing detectable enterotoxin, whereas there was only one serologically confirmed outbreak in which toxin was not detected. Thus faecal enterotoxin assayed by this ELISA confirmed 47 of $50(94 \%) C$ perfringens outbreaks compared with 32 of $48(67 \%)$ confirmed by serotyping.

We thank the directors and staff of the public health and hospital laboratories for sending outbreak faeces. We are also grateful to Dr SP Borriello, MRC Clinical Research Centre, Harrow, Middlesex, for providing faecal material for some of the control studies and are especially grateful to our colleagues in the Food Hygiene Laboratory who cooperated in the asymptomatic volunteer study. We also acknowledge the assistance, facilities, and advice of Dr P Hambleton and BJ Capel, Vaccine Research and Production Laboratory, PHLS-CAMR, in the monkey feeding experiments.

\section{References}

' Stringer MF, Turnbull PCB, Gilbert RJ. Application of serological typing to the investigation of outbreaks of Clostridium perfringens food poisoning 1970-1978. J Hyg (Camb) $1980 ; 84: 443-56$.

${ }^{2}$ Bartholomew BA, Stringer MF. Clostridium perfringens enterotoxin: a brief review. Biochem Soc Trans 1984;12:195-7.

${ }^{3}$ Public Health Laboratory Service. Food poisoning and salmonella surveillance in England and Wales: 1982. Br Med J 1984; 288:306-8.

4 Duncan CL. Time of enterotoxin formation and release during sporulation of Clostridium perfringens type A. J Bacteriol 1973;113:932-6.

s Skjelkvåle R, Stringer MF, Smart JL. Enterotoxin production by 
lecithinase-positive and lecithinase-negative Clostridium perfringens isolated from food poisoning outbreaks and other sources. J Appl Bacteriol 1979;47:329-39.

- Bartholomew BA, Stringer MF. Observations on the puritication of Clostridium perfringens type $A$ enterotoxin and the production of a specific antiserum. FEMS Microbiol Lett 1983;18:43-8.

' Granum PE, Whitaker JR. Improved method for purification of enterotoxin from Clostridium perfringens type A. Appl Environ Microbiol 1980;39:1120-2.

" Genigeorgis C, Sakaguchi G, Riemann HP. Assay methods for Clostridium perfringens type A enterotoxin. Appl Microbiol 1973; 26: 111-5.

" Steinbuch M, Audran R. The isolation of IgG from mammalian sera with the aid of caprylic acid. Arch Biochem Biophys $1969 ; 134: 279-84$.

${ }^{10}$ Nakane PK, Kawaoi A. Peroxidase-labelled antibody. A new method of conjugation. J Histochem Cytochem 1974;22: 1084-91.

" Stringer MF, Watson GN, Gilbert RJ. Clostridium perfringens type A: serological typing and methods for detection of enterotoxin. In: Corry JEL, Roberts D, Skinner FA, eds. Isolation and identification methods for food poisoning organisms. Society of Applied Bacteriology Technical Series no 17. London: Academic Press, 1982:111-35.

${ }^{12}$ Watson GN, Stringer MF, Gilbert RJ, Mahoney DE. The potential of bacteriocin typing in the study of Clostridium perfringens food poisoning. J Clin Pathol 1982;35:1361-5.

${ }^{13}$ Naik HS, Duncan CL. Rapid detection and quantitation of Clostridium perfringens enterotoxin by counterimmunoelectrophoresis. Appl Environ Microbiol 1977;34:125-8.

${ }^{14}$ Notermans S. Detection of staphylococcal enterotoxins using ELISA. In: Corry JEL, Roberts D, Skinner FA, eds. Isolation and identification methods for food poisoning organisms. Society of Applied Bacteriology Technical Series no 17. London: Academic Press, 1982: 199-209.

is McClane BA, Strouse RJ. Rapid detection of Clostridium per- fringens type A enterotoxin by enzyme-linked immunosorbent assay. J Clin Microbiol 1984;19:112-5.

${ }^{16}$ Olsvik O, Granum PE, Berdal BP. Detection of Clostridium perfringens type A enterotoxin by ELISA. Acta Path Microbiol Immunol Scand [B] 1982;90:445-7.

${ }^{17}$ Narayan KG, Genigeorgis C, Behymer D. Use of enzyme linked immunosorbent assay (ELISA) in the quantitation of Clostridium perfringens type $A$ enterotoxin and antienterotoxin antibodies. Int J Zoonoses 1983;10:105-10.

${ }^{18}$ Notermans S, Heuvelman C, Beckers H, Uemura T. Evaluation of the ELISA as tool in diagnosing Clostridium perfringens enterotoxins. Zentrabl Bakteriol Mikrobiol Hyg [B] 1984; 179:225-34.

${ }^{14}$ Skjelkvåle R, Uemura T. Detection of enterotoxin in faeces and antienterotoxin in serum after Clostridium perfringens foodpoisoning. J Appl Bacteriol 1977;42:355-63.

${ }^{20}$ Uemura T, Sakaguchi G, Itoh T, Okazawa K, Sakai S. Experimental diarrhoea in cynomolgus monkeys by oral administration with Clostridium perfringens type A viable cells or enterotoxin. Jpn J Med Sci Biol 1975; 28: 165-77.

${ }^{21}$ Naik HS, Duncan CL. Enterotoxin formation in foods by Clostridium perfringens type A. Journal of Food Safety 1977;1:718.

${ }^{22}$ Skjelkvåle R, Uemura T. Experimental diarrhoea in human volunteers following oral administration of Clostridium perfringens enterotoxin. J Appl Bacteriol 1977;43:281-6.

${ }^{23}$ Craven SE, Blankenship LC, McDonel JL. Relationship of sporulation, enterotoxin formation and spoilage during growth of Clostridium perfringens type A in cooked chicken. Appl Environ Microbiol 1981;41:1184-91.

Requests for reprints to: Dr Barbara A Bartholomew, Food Hygiene Laboratory, Central Public Health Laboratory, 175 Colindale Avenue, London NW9 5HT, England. 